\section{EC putting bite in its green bark}

\section{London}

BY day the Eurocrats of the European Communities are the green champions of Europe, passing more environmental legislation in the past three years than in the previous two decades. But by night, when they return to their Brussels homes, they are among the EC's worst polluters. One hundred per cent of the sewage in the EC capital flows raw and untreated into the North Sea. This, they admit, does not look good. Worse, it is a glaring reminder of the principal problem with the European Commission's environmental legislation. Its laws may be environmentally stringent, comprehensive and far-ranging, but they are also widely flouted.

Despite an aggressive record of green legislation -450 regulations are already in effect, and some 90 others are set to join them this year - the Commission has a reputation for toothlessness. Beyond Belgium's sewage, there are Britain's seashores, rivers and drinking water, Italy's air and Greece's birds. More than 400 cases of non-compliance are now being argued in the European Court. Several members states have failed to ratify - and make national law - even half of the EC directives.

The problem is that, while the European Commission has become very good at passing rules, it has given itself precious little with which to enforce them. It has no inspectors to find out if its directives are being followed, and no comprehensive monitoring programme to gauge the effect of the rules that are being kept. Typically, the only way the Commission learns that a country is violating a directive is when some citizen writes a letter of complaint. Even then, all the Commission can do is file a lawsuit with the European Court, a process that often takes three or more years; it has no power to levy fines.

"In general, the implementation [of EC environmental regulations] has been slow, and it has been patchy," says Ted Bennett, head of the EC's Industry and Environment directorate.

Earlier this year, the Communities' Environment Commissioner, Carlo Ripa di Meana, announced plans for the EC's first force of environmental inspectors 'green police' - who would inspect member states to see if they are complying with EC laws. The inspectors should be able to levy fines, Meana said.

EC officials are also looking to economics to help stem the leak in their enforcement dike. Last year, after the European Council of Ministers declared that standards alone were no longer enough and called on the Commission to use its economic leverage to bring member states into line, an EC working group laid out five economic 'tools' to encourage environmental compliance: subsidies, deposit-refund systems, emissions trading, taxes and fines.

Community pressure for a tax on carbon dioxide emissions quickly brought the debate on economic measures to the fore, and they are expected to figure prominently in a major revision of the EC Treaty later this year. EC officials say that subsidies will probably be used only where compliance would cause serious economic disruption, such as the possible consequence of reducing fertilizer use in farming.

Taxes, apart from those on carbon dioxide, are planned mostly to generate revenue to subsidize other enforcement systems, such as inspectors. Meanwhile, emissions-trading schemes are expected to be introduced to help control release of sulphur dioxide, nitrogen oxide, volatile organic compounds and particulates.

But the hurdles that still lie between the EC's rules and practised reality are considerable. After 20 years of EC environmental legislation, the compliance barriers that remain include the following.

- Cost of compliance: If the EC rules were just an endorsement of the status quo, compliance would be no problem. But in most cases they go beyond existing national legislation in many of the member states, and bringing those countries into line is not cheap. In Britain, for example, the cost of implementing just one - reducing sulphur levels in gasoline - will cost refineries some $£ 270$ million. Upgrading sewage treatment to conform with $\mathrm{EC}$ regulations will cost the UK $£ 1,500$ million over the next decade.

- National politics: "It's actually quite hard to write a national law that will follow an EC directive," says one UK environmental official. In Belgium, for example, the constitution has a federal-state separation clause that makes if very difficult to write federal legislation without violating state rights.

- Lack of good data: Environmental monitoring among the EC member states is still patchy, suffering from a mishmash of measuring techniques and differing national reporting policies. Without a clear picture of what is being released where, the EC can hardly find trouble spots. Last year, it created a European Environment Agency to start a comprehensive monitoring and data gathering programme, but the agency (see below) has been tangled in politics since its inception and has yet to get a home.

Christopher Anderson

\title{
New environmental agency hijacked by politics
}

THE future of the new European Environmental Agency has been held hostage to EC politics since its announcement last year. France insists that there will be no decision on a home for the agency nor further decisions on its purpose until the EC states resolve the question of where to locate the headquarters of the European Parliament, a debate that is already a half-decade old and with no end in sight.

That is unfortunate, because the environmental agency's mission - to compile and distribute data about Europe's environment - is critical. Environmental data plotted on a map sometimes shows political boundaries not because the air is different across the borders, but because the measuring systems are. It is hard to make en- vironmental policy without accurate information.

A working environment agency could provide the EC with just that. Approved in March last year with funding of about 5 million ECU, the agency does actually exist, in a way. It has a director and a small staff in Brussels. But until it gets a real headquarters and its marching orders, it can do little but farm out small datagathering contracts to some of the institutions vying to be its home.

The agency is expected eventually to focus on data collection and dissemination, acting as an 'interface' between basic environmental research and environmental policy.

Eleven of the 12 member states have put in bids for the agency, including the
Netherlands, whose National Institute of Public Health and Environmental Protection (RIVM) is already well on the way towards compiling environmental data for the entire continent.

EC environment minister Carlo Ripa Di Meana is fighting hard to have the agency 'unlinked' from the question of the Parliament's location, but he has so far met with little success. In the meantime, Italy, France and the United Kingdom have all announced plans for agencies of their own, to monitor and research their domestic environments. Ideally, these agencies should be working with the European Environment Agency to set common data polices. But with its future still in the air, there is not much the agency can do to help. 